\section{Entrepreneurial dynamics and investor-oriented approaches for regulating the equity-based crowdfunding}

Regulating the equity-based crowdfunding

Antonella Francesca Cicchiello

Catholic University of Sacred Heart, Piacenza, Italy, and

Maria Cristina Pietronudo, Daniele Leone and Andrea Caporuscio

Parthenope University of Naples, Naples, Italy

\begin{abstract}
Purpose - The aim of this research is to contribute to the existing literature about the entrepreneurial conditions in crowd-based contexts by describing how different European countries regulate equity crowdfunding market in order to incentive the investments and protect investors.

Design/methodology/approach - Based on a legal acts' analysis, we conduct a qualitative study comparing the crowdfunding regulation addressed to investors. In particular, we focus our analysis on the European countries with the highest concentration of crowdfunding platforms (i.e. the UK, Germany, France, Italy and Spain).

Findings - The results show that some countries, such as the UK, Germany and France, present an investororiented approach based on non-restrictive regulation, while other countries, such as Spain and Italy, have a restrictive approach that protects investors excessively and discourages them. In particular, the case study of France shows how the introduction of unrestricted regulation can produce positive effects on the volume of crowdfunding transactions.

Practical implications - The paper is addressed to investors, policymakers and intermediaries (platforms) to help the first in orienting themselves between the different crowdfunding regulations and the latter in aligning and orchestrating rules and norms.

Originality/value - This is the first study that analyses the role of investor-oriented regulations in the promotion of entrepreneurship through the identification of four key factors to monitor equity crowdfunding regulations.
\end{abstract}

Keywords Regulation, Equity crowdfunding, Investments, Entrepreneurs, Start-ups, Innovation

Paper type Research paper

\section{Introduction}

With the constant increase of innovations in developed countries, and with the need of defining essential regulation in developing countries, nowadays, policymakers in the crowdbased contexts must be able to ensure that users can invest with security and transparency, with defined rights, and rules first of all. Crowdfunding (henceforth: $\mathrm{CF}$ ) is an interesting fundraising phenomenon for startups, SMEs and individual entrepreneurs. It can be defined as a "method for funding a variety of new ventures, allowing individual founders of for-profit, cultural, or social projects to request funding from many individuals, often in return for future products or equity" (Mollick, 2014, p. 1). The literature identifies four main types of crowdfunding depending on how investors arerecompensed (Mollick, 2014). In the donationbased model, people donate money without expecting something in return led by altruistic

(C) Antonella Francesca Cicchiello, Maria Cristina Pietronudo, Daniele Leone and Andrea Caporuscio. Published by Emerald Publishing Limited. This article is published under the Creative Commons Attribution (CC BY 4.0) licence. Anyone may reproduce, distribute, translate and create derivative works of this article (for both commercial and non-commercial purposes), subject to full attribution to the original publication and authors. The full terms of this licence may be seen at http://creativecommons.org/licences/by/4.0/legalcode

This paper forms part of a special section "Startup Innovation: The Role of Regulation in Entrepreneurship”, guest edited by Richard A. Epstein, Seth Oranburg and Liya Palagashvili.
Received 14 March 2019 Revised 19 November 2019 Accepted 15 June 2020

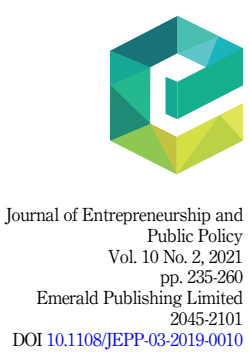


JEPP

10,2

motivations. The reward-based model is mainly used for creative projects and allows investors to finance a project and obtain non-monetary rewards or products in return. In the lending-based model, individuals lend money to businesses (P2B) or other individuals (P2P) with the expectation that it will be repaid together with interest added. Finally, the equitybased model enables investors to fund startups and SMEs in return for a small equity stake.

Over the past decade, equity-based crowdfunding (henceforth:ECF) has established itself as a new player in the entrepreneurial finance market, able to support seed and early-stage financing of entrepreneurial projects and provide consumers with an excellent opportunity to become investors and take advantage of their knowledge in financial matters. ECF also involves institutional investors, such as venture capitalists or business angels, who also enjoy benefits from this phenomenon (Agrawal et al., 2014; Bade, 2018). Its role in supporting entrepreneurship, employment creation and spur growth has grown rapidly across Europe demonstrating its ability to deliver capital more efficiently to a large number of businesses and entrepreneurs than has been possible in the past.

The rapid growth of crowdfunding has created serious challenges for European policymakers and regulators and has drawn the attention of the academic world (Moritz and Block, 2016)D. Some European Member States have introduced tailored domestic regimes in response to challenges arising from crowdfunding relating to investor protection. Instead, other countries have relied on existing regimes governing financial intermediation by adjusting them according to the characteristics and needs of crowdfunding local markets and investors.

Still today, however, the lack of appropriate regulations creates an unpredictable environment and a state of uncertainty which is deterring investors and, as a consequence, strangles equity crowdfunding investments (Cicchiello, 2019a). According to Ziegler et al. (2018), the more investors and platforms perceive that the existing crowdfunding regulatory framework is adequate in their countries, the more likely these countries to exhibit higher crowdfunding volumes per capita, as well as a larger share of business funding. Therefore, the success of ECF depends on the ability of each country to develop forward-thinking regulations that can support this new funding model while providing the right level of protection for crowdfunding investors (Cicchiello, 2019b). The growing literature on crowdfunding focuses mainly on the theoretical conceptualisation and main elements and business models of this phenomenon (Agrawal et al., 2014; Belleflamme et al., 2014). A further stream of research studies about ECF focuses on the different elements and strategies that help startups or entrepreneurs to get their projects funded, such as: network size (Shane and Cable, 2002), communication and professionalism (Müllerleile and Joenssen, 2015), risk factors (Ahlers et al., 2015), internal social capital (Colombo and Franzoni, 2015). Other scholars paid attention to the knowledge sharing among creators and backers during the different stages of the crowdfunding project (Leone and Schiavone, 2018) and to the post-campaign operational problems hindering promised rewards to the funders (Leone et al., 2018).

The aim of this research is to contribute to the extant literature about the entrepreneurial conditions in crowd-based contexts by describing how different European countries organise regulation aspects in order to incentive the investments and protect investors. Surprisingly, very few authors paid attention to regulation issues faced by startups or individual entrepreneurs investing in ECF projects. In particular, the process behind the direct and indirect regulations is known just superficially. For these reasons, we identify four key factors to explore the different mechanisms of the ECF regulations: 1) reliability of the investor, 2) the investment requirements, 3) suitability and 4) disclosure and transparency of the platforms. Thus, the research investigates the following research questions: how does crowdfunding regulation provide measures to protect investor? Which factors impact on investor regulation? This paper adopts an exploratory approach and conducts a comparative analysis in order to answer these questions. The analysis focuses on European countries with the highest concentration of crowdfunding platforms, that is the UK (with more than 40 


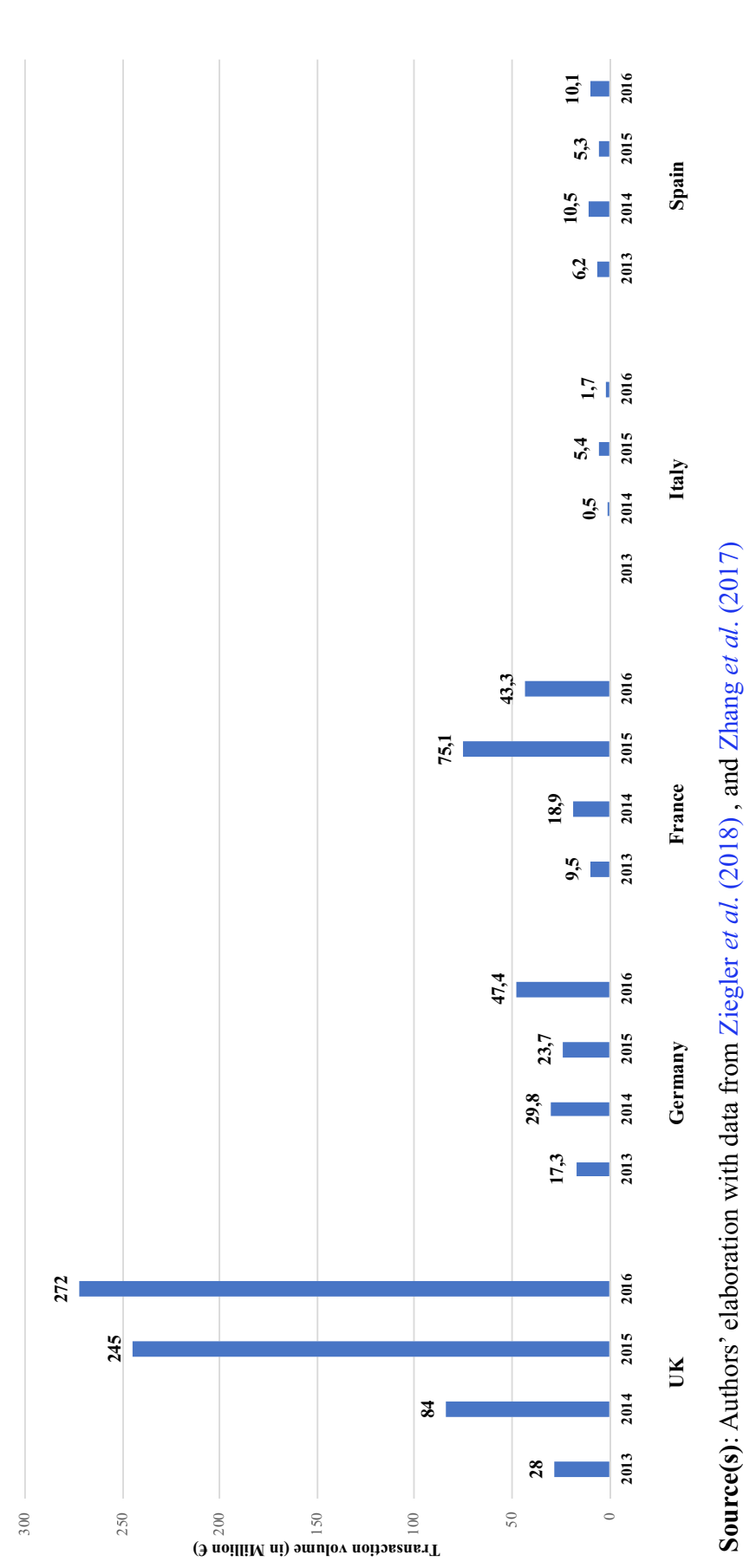

Regulating the equity-based crowdfunding

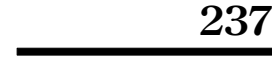

Figure 1. Equity-based crowdfunding transaction volume by country from 2013 to 2016 (in million euros) 
JEPP

10,2

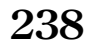

platforms), Germany (35), France (33), Spain (32) and Italy (26) (Ziegler et al., 2018). Figure 1 shows the equity-based crowdfunding transaction volume in the analysed countries.

The results show that some countries, such as the UK, Germany and France, have an investor-oriented approach based on non-restrictive regulation that protects and promotes investors. As a consequence, these countries record a high volume of investment from the crowd. Other countries, such as Spain and Italy, have instead a restrictive approach that protects investors excessively and discourages them.

The research is structured as follows. Section 2 in-depth analyses the main literature on entrepreneurial conditions in crowd-based contexts, and on the different levels of investor protection in equity crowdfunding. Section 3 briefly describes the methodology used to investigate the different regulations across Europe explored in section 4 . Section 5 discusses the results of the proposed descriptive model. Finally, section 6 summarises the main conclusions and implications of the study.

\section{Theory background}

\subsection{The relevance of the institutional environment for entrepreneurship}

Due to the difficulty in convincing investors, many innovative entrepreneurial initiatives do not have sufficient financial resources (Casamatta and Haritchabalet, 2007). The funding procurement phase is the most crucial for startups (Cosh et al., 2009). To overcome this problem, many entrepreneurial initiatives turn to the "crowd" rather than specialised investors. Crowdfunding is a valuable tool for small business ventures to get the capital needed to start the business (Schwienbacher and Larralde, 2012). According to Mollick (2014), crowdfunding is a financial instrument strongly influenced by the context of the crowd, which can finance small entrepreneurial initiatives. Entrepreneurs can exploit the mechanisms of the crowd through virtual platforms (Belleflamme et al., 2013). The interactions within the crowd are important, in fact, the behaviour of some actors could influence the decisions of the other members. These dynamics within crowdfunding initiatives can jeopardise the final outcome (Ward and Ramachandran, 2010).

From a managerial perspective, crowdfunding can be considered not only as a financial source, but also as a validation instrument in stimulating entrepreneurship. Following this line, the entrepreneurial context is a crucial factor in financial choices for a positive development of startups (Kempster and Cope, 2010). For these reasons, it is useful to analyse the various approaches in previous studies, in order to analyse the key factors that contribute in labelling ECF regulations as "restrictive or not restrictive". The institutional environment refers to all formal and informal structures that regulate economic activity in a given milieu (Hart and Milstein, 2003). The formal structures are all those institutions and norms that influence the degree of entrepreneurship in a particular region or country (Autio and Acs, 2010). Informal institutions have an impact on the degree of entrepreneurship through social and ethical rules that are strongly connected with the idea of the legality of the actors present in the context (Levie and Autio, 2011). Therefore, norms are a crucial factor in the characterisation of the entrepreneurial context (Porter and Kramer, 2006). In agreement with Acemoglu et al. (2005), the entrepreneurial initiative is strongly conditioned by the security and stability of the external context. This work highlights the important role of the regulatory aspects in boosting entrepreneurial practices. The establishment of a series of rules and regulations to protect and safeguard investors and founders is necessary for a secured crowdfunding market (Heminway, 2016). One of the main scopes of the regulation is, in fact, protecting investors to "maintain their confidence in the markets' integrity, and the encouragement of capital formation" (Frankel, 1998, p. 1325).

Consequently, a broad and consistent spectrum of regulation is needed (Heminway, 2016) to guarantee in addition to transparency towards the investors. Their role is nevertheless 
crucial to building a crowdfunding market and maintain confidence in this form of investment (Nehme, 2018). In fact, some authors (Hornuf and Schwienbacher, 2016) have underlined how some rules as the exemption from the prospectus requirement may impact on investor participation in crowdfunding campaigns and compromising in case of low protection and low transparency the involvement of these no-sophisticated investors.
Regulating the equity-based crowdfunding

\subsection{Exploring mechanisms behind ECF regulations for investment choices}

The market alone is unable to adequately regulate equity crowdfunding (Heminway, 2016); in fact, previous studies attested the necessity to well define regulation, and provide incentive and protection for crowdfunding actors (Belleflamme et al., 2014; Pesok, 2014; Hornuf and Schwienbacher, 2017; Cicchiello et al., 2019). Regulation is a natural response to internal and external negative facts like systemic risk caused by asymmetric information, lemon problems (Lee, 2019; Cable, 2014) or other events that compromise the stability of the market. Studies on investor protection are fragmented and should be derived from papers on ECF regulations. Furthermore, it is very complicated build a general framework on the form of investor protection because regulation is territorially based (Brummer, 2011) and it depends on the context and the funding amount (Mollick, 2014). However, existing literature (Cable, 2014; Pierce-Wright, 2016; Nehme, 2018) has identified two groups of jurisdictions in terms of less or more restrictiveness (Financial Conduct Authority, 2017). The more inhibitory ones, based on limitation size of proceeds and the size of permissible investments, are very common in the international scenario. In drafting ECF legislation, the level of pervasiveness and restrictiveness is tricky to manage, because of influencing consistently a successful exploitation of such financial tool. Indeed, a high level of restriction, thereby, not only is not sufficient to protect investors, but also includes stricter requirements for SMEs and startups (World Bank, 2013; Hornuf and Schwienbacher, 2016).

Accordingly, we may wrap up that a sensitive factor is the investment requirements, by means of unuseful overprotection that hinders the growth of the crowdfunding market (Lee, 2019). The threshold of investment is an affordable issue for evaluation of restriction in ECF regulation. Indeed, some scholars analysed the policy maker outcome as intertwined with the cultural country features (Ripken, 2015). Therefore, these studies consider a restrictive set of rules stemmed from legal paternalism. Such circumstances lead the legislator to be worried about the protection of investors, characterised by inexperience or irrational decisions, trying to avoid the production of adverse events for investors. "The Jumpstart Business our start up act" is a law aimed to stimulate the take-off of small firms. It has been extremely breakthrough, particularly in influencing the rules concerning crowdfunding. It broke the barriers down for the unaccredited shareholders especially by establishing several standards related to the permitted amount in crowdfunding campaign. The norms becoming less restrictive, have been a reliable case to test the impact of less protection. The degree of information disclosure is another sensitive indicator of restrictiveness. In attrition to the restrictions applied by protective jurisdictions, it is essential that some and other forms of protection are concerned with guaranteeing proper information disclosures (Cable, 2014).

The "Jumpstart Our Business Startups Act" has been disruptive also in the part concerning the mandatory disclosure. According to Schwartz (2018) less restrictive norms enable to join the crowdfunding campaign by saving costs in disclosure documentation. Currently, a proper level of disclosure is required by the educational material equipped by the platforms (Pierce-Wright, 2016) which explain the investment process with regards to the types of securities offered, the information required by the issuer to investors, the restrictions on the resale of securities and investments limits (Lee, 2019). Schwartz (2018) conducts a comparative analysis, between USA and New Zealand, about the effects of narrowing the disclosure requirements on the startups' performance, revealing a greater level of the financial success of crowdfunding in New Zealand than in the United States. The author 
JEPP

10,2

attributes this outperformance to the fact that New Zealand's system, unlike that of the US, is focused solely on efficiency, even at the expense of inclusivity.

Disclosure protects might boost the investors by enlarging the stream of the necessary information. It is fundamental first of all, when a component of the same system has unequal access to information, typically due to a lack of access to information sources or a lack of adequate resources (Heminway, 2014). In addition, the online portals ensure transparency and communication between potential investors, who share information with each other, allowing the knowledgeable to guide the uninformed (Fisch, 1998; Pierce-Wright, 2016).

The most quoted studies on ECF legislation carry out another parameter of restrictiveness such as the reliability of investor. Reliability is a feature of investor strictly related to the ability to appear trustworthy on the market by launching signals of solidness and consistency. It means that the policy maker could be particularly interested in making rules aimed to stimulate the proliferation of reliable behaviour. The normative approach in terms of restrictiveness could affect the reliability of incoming investor. A trustworthy investor plays an important role within an ECF campaign. Thus, the degree of reliability is a pivotal factor in the view of scaling up the stability of the entire system. The trust might mitigate the drawbacks of asymmetry by empowering more and more times the efficiency and reducing the level of uncertainty and complexity of online transactions. According to above mentioned studies, we identify the suitability as a triggered factor. It refers to the potential customer's information with specific reference of knowledge and experience level and financial state (Cumming and Hornuf, 2018). Another point of view refers to the suitability test able to measure the investor's capacity to bear losses in order to permit the investment firm to advise suitable services.

Drawing on these assumptions, it is possible to develop a conceptual model to establish a clear structure able to distinguish different mechanisms for the ways in which ECF regulations influence investors (Figure 2). However, the crowdfunding markets require other forms of protection to reduce information asymmetries and problems of fraud and lemons, also trying, in the same time, to focus itself on the facilitating of investment transactions. Hence, huge challenges will concern policymakers and regulators who should balance the interests of young enterprises, intermediaries and investors, encouraging innovation while they ensure a financial stability and the soundness and the integrity of market (Lee, 2019). Not surprisingly, from the analysis of cases dealt with in the literature-regulations in the US, the UK, New Zealand, Hong Kong and various jurisdictions - (Klöhn et al., 2016; Pierce-Wright, 2016; Lee, 2019; Nehme, 2018) emerge common needs: safeguarding crowdfunding from the self-regulation pushed by the market, adopting rules less rigid and protective, and promote a greater education of investors. In this way, a loss of attraction of what is the new alternative to traditional financing will be avoided.

Only when investors are adequately protected, they can trust this instrument, and so use it more, with clear benefits for companies. On the other hand, the development of crowdfunding market cannot be separated from appropriate incentives to encourage entrepreneurial initiatives (Hornuf and Schwienbacher, 2017; Cicchiello et al., 2019).

\section{Research method}

The following section discusses the methodology used to analyse the regulatory issues that relate to investors' protection in Europe adopting an explorative approach. Five European countries were analysed in order to o provide a detailed and descriptive examination of regulations and a comparative analysis between jurisdictions. In particular, the analysis focuses on the UK, Germany, France, Italy and Spain, which are the European countries with the highest concentration of crowdfunding platforms (Ziegler et al., 2018). Based on legal acts' analysis, the study first examines the main legal requirements in the investors' field which are implemented in the national laws of the analysed countries. This research method provides significant insight into how protection for investors differs from country to country by 


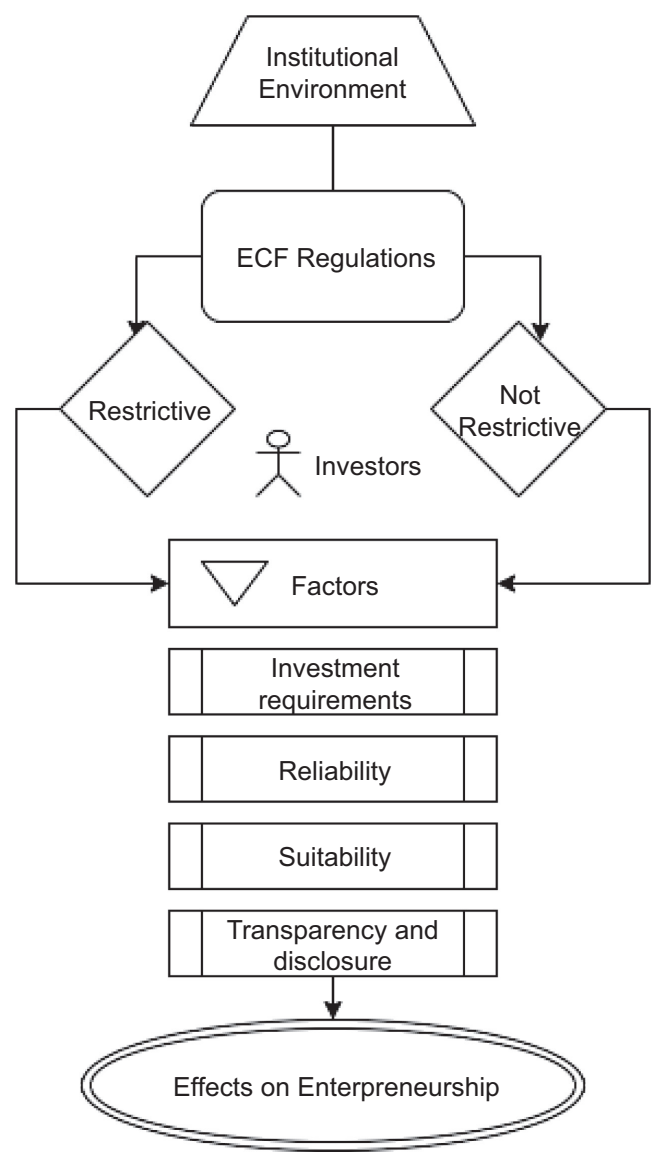

Regulating the equity-based crowdfunding

making a comparison among them. Descriptive studies are useful to "draw a picture" of a phenomenon (Gray, 2010). Therefore, we conducted a qualitative study in order to define a descriptive model of crowdfunding regulatory aspects to incentive investments and protect investors.

To be as understanding as possible, we used data extracted from legal acts through a content analysis. We focused our descriptive analysis on regulatory aspects which, by their very nature, are likely to encourage (or discourage) risk-taking and investment in non-listed companies, and as a consequence, promote (or block) the development of equity crowdfunding.

The research is explored using the following specific purposes:

(1) understanding how protection for investors differs from country to country;

(2) providing recommendations and future practices to implement an investor-oriented approach for regulation on equity crowdfunding.

\section{A comparative analysis across Europe}

For the purposes of this paper, five countries have been selected to highlight how varied regulation on crowdfunding that applies to investors are designed and implemented in 
JEPP

10,2

242

different jurisdictions. This sample provides significant insight into how protection for investors differs from country to country by making a comparison among the different national laws. The analysis includes the UK, Germany, France, Italy and Spain which are among the top five countries utilising crowdfunding channels to support businesses. These countries have implemented specific crowdfunding regulations by including a "Crowdfunding Exemption" into their existing legal frameworks which exempts crowdfunding from (some or most of) the general financial services regulation. For each of the analysed countries, Table 1 shows the national crowdfunding laws, the date of entry into force and the scope. According to the European Commission report (2017), the presence of a specific regulation for crowdfunding has boosted the crowdfunding market in these counties.

\subsection{The UK}

The Financial Conduct Authority (FCA) has provided in the United Kingdom flexible rules for equity-and lending-based crowdfunding platforms through the Policy Statement (PS14/4) entered into force on 1st April 2014. To carry out fundraising activities, platforms must be authorised by the FCA. The registration in an official register is not required.

To ensure an adequate level of crowdfunding investors protection, the English law classifies them into three categories:

(1) sophisticated investors, i.e., investors who: $(\bullet)$ certify to be member of a network or syndicate of business angels from at least 6 months; $(\bullet)$ to have made more than one investment in an unlisted company in the previous two years; $(\bullet)$ to have worked over the last two years in the private equity sector, or in the provision of finance for SMEs; $(\bullet)$ or to have been in the last two years a director of a company with an annual turnover of $£ 1$ million or more;

(2) high-net-worth investors, i.e., investors that earn at least $£ 100,000$ a year or have at least $£ 250,000$ in assets, excluding principal residence, insurance, and pension policies; and

(3) unsophisticated investors, i.e., retail clients who receive an investment advisory or investment management service from an authorised person.

While the first two categories are not subject to investment limits, the third category of investors (i.e. retail investors) is not allowed to invest more than $10 \%$ of their net investable

\begin{tabular}{|c|c|c|c|}
\hline & National crowdfunding laws & $\begin{array}{l}\text { Entry into } \\
\text { force }\end{array}$ & Scope \\
\hline UK & $\begin{array}{l}\text { The FCA's Policy Statement (PS14/4) of March } \\
2014\end{array}$ & $\begin{array}{l}\text { 1 April } \\
2014\end{array}$ & Securities and lending \\
\hline Germany & $\begin{array}{l}\text { The Small Investor Protection Act } \\
\text { (Kleinanlegerschutzgesetz) }\end{array}$ & $\begin{array}{l}10 \text { July } \\
2015\end{array}$ & $\begin{array}{l}\text { Crowdinvesting and } \\
\text { crowdlending (Equity- and } \\
\text { lending-based crowdfunding) }\end{array}$ \\
\hline France & $\begin{array}{l}\text { Order No. 2014-559 of } 30 \text { May } 2014 \text { on the } \\
\text { participatory financing }\end{array}$ & $\begin{array}{l}1 \text { October } \\
2014\end{array}$ & $\begin{array}{l}\text { Equity-and lending-based } \\
\text { crowdfunding }\end{array}$ \\
\hline Italy & $\begin{array}{l}\text { Law Decree No. } 179 \text { of } 18 \text { October } 2012 \text { on } \\
\text { further urgent measures for Italy's economic } \\
\text { growth }\end{array}$ & $\begin{array}{l}26 \text { June } \\
2013\end{array}$ & Equity-based crowdfunding \\
\hline Spain & $\begin{array}{l}\text { Law 5/2015 on the promotion of corporate } \\
\text { financing (Ley de Fomento de la Financiación } \\
\text { Empresarial) }\end{array}$ & $\begin{array}{l}29 \text { April } \\
2015\end{array}$ & $\begin{array}{l}\text { Equity- and lending-based } \\
\text { crowdfunding }\end{array}$ \\
\hline \multicolumn{4}{|c|}{ Source(s): Authors' elaboration } \\
\hline
\end{tabular}

Table 1.

Overview of national crowdfunding laws in the UK, Germany, France, Italy and Spain 
assets (excluding their principal residence, pension and life cover) within a 12-month period. Since the UK, investors are required to self-certify their belonging to one of the above categories, the law requires platforms to provide detailed information about potential losses and all risks involved in crowdfunding investments. Platforms must carry out a screening process to identify the non-sophisticated investors. Equity crowdfunding platforms may offer investors equities and debt securities, transferable and non-transferable. Non-readily realisable securities (NRRS) can be offered only to sophisticated investors, high net worth investors and advised investors.

Crowdfunding offers of less than $€ 5$ million in a period of 12 months are exempted from the publication of the prospectus normally required by the law when transferable securities are offered to the public. Although the UK legislation regulates platforms' activity, crowdfunding practices are largely unregulated, leaving platforms the possibility to not make their screening processes for potential campaigns public. The UK Crowdfunding Association (UKCFA), set up as a self-regulatory trade body by several UK crowdfunding businesses, published its own code of conduct. The code focuses mainly on investors' protection.

\subsection{Germany}

The German government started to lay the foundation to create a reliable legal framework for crowdfunding and other new forms of financing with the Small Investor Protection Act (Kleinanlegerschutzgesetz), passed by the German Bundestag (Federal Parliament) on 23 April 2015. Entered into force on 10 July 2015, the Small Investor Protection Act contains a regulation tailored to project and company financing through specialised crowdinvesting and crowdlending platforms (equity and lending-based platforms, respectively). According to the German Banking Act (Kreditwesengesetz), the provision of financial services requires a written licence from the German Federal Financial Supervisory Authority (Bundesanstalt für Finanzmarktaufsicht, BaFin).

Thus, crowdfunding platforms facilitating the offering of securities, investment products (Vermögensanlagen) or shares in collective investment undertakings (Investmentvermögen), must be authorised by BaFin, the reference authority in charge with investment-based crowdfunding issues.

Investment products (Vermögensanlagen) include:

(1) subordinated loans (Nachrangdarlehen);

(2) profit participating loans (partiarische Darlehen); and

(3) commercially comparable investments (wirtschaftlich vergleichbare Anlagen).

In order to qualify for a statutory exception to the licensing requirement, most of the German platforms offer silent participations (stille Beteiligungen), subordinated profit-participating loans (partiarische Nachrangdarlehen), profit participation rights (Genussrechte) or (partial) repayment claims ((Teil)Rückzahlungsansprüche) in case of $\mathrm{P} 2 \mathrm{P}$ lending.

The exclusion of fundraising through equity shares and of companies registered as GmbHs (the private limited liability status most commonly chosen by Germany startups) from the exemption to the licensing requirement has limited the development of the Germany equity crowdfunding industry. As a consequence, the equity-based Crowdfunding has experienced over the years a significant decline in total volume. Equity-based platforms must be classified as investment service enterprise providing investment advice or investment brokerage services (MiFID) according to the definition of the German Securities Trading Act (Wertpapierhandelsgesetz); or be subject to authorisation and monitoring by general trade regulatory authorities. There is not an official national registry of investment-based crowdfunding platforms. 
JEPP

10,2
For platforms providing investment advice or investment brokerage services (i.e., MiFID platforms) the minimum capital requirements depend on the MiFID investment services and activities provided. These platforms must provide an investment information sheet (VIB) to potential investors, in good time prior to purchase of the investment. Platforms with a commercial license must subscribe to a professional liability insurance. Equity crowdfunding platforms must verify the suitability or appropriateness of the investment pursuant to the Securities Trading Act or the Financial Investment Brokerage Ordinance.

Platforms managers must provide evidence of their reliability and expertise by passing the exam conducted by the Chamber of Industry and Commerce. To identify possible conflicts of interest, platforms managers must disclose any fees, payments or other monetary benefits that they receive from third parties other than investors in respect of the services provided.

Companies seeking to make an offer are exempted from the prospectus publication requirement if the aggregated value of the issued investments does not exceed $€ 6$ million ( $€$ 2.5 million, previously). Non-issued and already repaid investments do not count to the threshold for a prospectus requirement. Even in the case of exemption from the prospectus publication, companies must prepare an investment information sheet (VIB) containing: (1) the warning notice about the risks associated with the investment and the potential total loss of the invested money; (2) a notice that there is no prospectus approved by BaFin and (3) a notice that further information may be requested.

The VIB must be submitted to BaFin and investors must confirm that they have taken note (by signature or equivalent) of it. Companies are civilly responsible if the VIB is misleading or inaccurate. Unlike the other analysed countries, Germany law does not make a distinction between different types of investor, such as retail and professional investors.

The Germany Regulator has provided subscription limits in securities and other investment assets (Vermögenanlagen) only to investors who are not corporate entities, depending on their freely available assets and monthly net income. In particular, if the investor provides a statement that the amount of its freely available assets is at least $€$ 100,000 , it can invest up to $€ 25,000$ (€ 10,000 , previously) per year and per project. If the investor states to have a lower amount of assets, the investment limit is set to the double of his monthly net income, but in any case, not more than $€ 25,000$. When the investor does not provide the statement on its freely available assets and monthly net income, the individual investment is limited to a maximum of $€ 1,000$, per year and per project. Investors who invest through a special holding company ( $\mathrm{GmbH} \& \mathrm{Co} \mathrm{KG})$ can invest beyond the $€ 25,000$ limit.

\subsection{France}

France has been the second country, after Italy, to set up a regulatory framework to crowdfunding platforms on 14 February 2014 (Ordonnance n. 2014-559 du 30 mai 2014 relative au financement participative). The French regulation, entering into force on 1 October 2014 and then revised by the Law no. 2015-990 (Loi Macron) in 2015, has created two industry-specific statutes for crowdfunding platforms, both subject to anti-money laundering and anti-terrorism regulations:

(1) Intermediaire en Financement Participatif (IFP), an investment intermediary for lending-based crowdfunding, and since 1 December 2016 also for donation and reward platforms; and

(2) Conseiller en Investissement Participatif (CIP), an advisor for investment in equitybased crowdfunding.

IFP and CIP platforms shall be authorised and operate under the supervision of the Authority of Financial Markets (AMF-Autorite des Marchés Financiers) and the National Financial Services Regulator (ACPR-Autorité de Contrôle Prudentiel et de Résolution). 
IFP and CIP status are optional and platforms could choose instead to operate as a credit institution or as an Investment Services Provider (PSI-Prestataire de Services d'Investissement). In this latter case, platforms may provide the following investment services defined by the AMF (Article D.321-1 of the Monetary and Financial Code):

(1) reception and transmission of orders for third parties;

(2) execution of orders for third parties;

(3) dealing on own account;

(4) portfolio management for third parties;

(5) investment advice;

(6) underwriting;

(7) placement with and without guarantee;

(8) operation of multilateral trading facilities.

Since 1 October 2016, PSI and CIP platforms can offer to the investors:

(1) ordinary shares;

(2) preferred shares with voting rights attached;

(3) straight bonds;

(4) convertible bonds; and

(5) Mini-bonds, a debt instrument allowing to invest in a company and receive a fixed return over a set period of time, with the initial investment returned at the end of the prescribed duration.

The list of all authorised French investment-based platforms is published on the ORIAS website, the French association in charge of the Single Register of Insurance, Banking and Finance Intermediaries.

Foreign platforms that wish to offer loans, securities or similar instruments to French investors have to be registered as CIP, PSI or IFP. This condition makes the French crowdfunding market less attractive to foreign platforms.

Platforms must subscribe to a professional liability insurance policy (this being mandatory as from 1 July 2016). The presence of such insurance policy reduces the risk for investors in the event that a project does not develop in an expected manner.

In addition, platforms managers and administrators must provide proof that they have an appropriate level of professional skills and good repute and integrity.

The compliance with the abovementioned requirements allows platforms to use the label of "Plateforme de Crowdfunding Régulée par les Autorités Françaises" showing that they have been approved by the French authorities. This labeling of the platforms increases the investors' confidence.

To ensure an adequate level of investor protection, French regulation states that platforms shall comply with legal good conduct and organisation rules. Moreover, to ensure that investors' interests are protected, platforms must perform due diligence in selecting the projects and disclose the predetermined criteria used in the selection process (European Commission report 2017).

For reasons of transparency, the article 325-35 AMF Regulation requires the publication on the platforms' website of visible and easily accessible information about its corporate name, the address of its registered office, its status of advisor in participative investments, its

Regulating the equity-based crowdfunding 
JEPP

10,2

\section{6}

registration number in the ORIAS register and the risks related to the investment in securities. IFP platforms shall publish on their website, prior to 30 June of every year, an annual report regarding the previous calendar year of operations.

In accordance with article 217-1 AMF Regulation, when an offer of securities is not subject to the prospectus requirement approved by the $\mathrm{AMF}$, the issuer must provide (before any subscription) an adequate level of information including:

(1) the description of its activity and its project with the last statutory accounts, the financial projections and the organizational chart of management and shareholders;

(2) the level of participation of the management in the project;

(3) the details of every right attached to the securities offered (voting rights, financial rights and information rights);

(4) the details of every right (voting rights, financial rights and information rights) attached to the securities and to the categories of securities not offered and, the categories of beneficiaries of such not offered securities;

(5) a description of the risks and costs related to the issuer's activity and project.

The issuer is responsible for the completeness, accuracy and the balanced nature of the information provided, that must be written in non-technical language. The platform shall monitor that the issuer provides consistent and clear information.

Pursuant to the provisions of article 314-106 AMF Regulation, when securities offer is subject to a prospectus requirement, this one is sent to the investors with additional information about the risks and costs related to the subscribe securities.

Unlike some other European countries (such as the UK and Spain), French regulation does not provide restriction with regard to the type of investors, the number of investors, or maximum investment limits (per project and per year) [1]. However, to ensure that the risk involved in securities offering is suited to the investors' financial situation, experience, and risk profile, the access to platforms is restricted only to registered investors who have to undergo a suitability test. In case of mismatch, the platform has to refuse the investor's subscription.

The national crowdfunding association-Financement Participatif France (FPF) establish a code of conduct that can be voluntarily adopted by its members.

\subsection{Italy}

Italy was the first European country to define a bespoke regime for equity-based crowdfunding by the Law Decree 179 of 18 October 2012 (Decreto Crescita 2.0) on "Further urgent measures for Italy's economic growth." The law decree was then implemented by the Italian Securities and Exchange Commission (CONSOB) Regulation n.18592 of 26 June 2013 on the collection of risk capital by innovative startups through online portals. At first, the public offer of equity participations through online portals was restricted solely to the "Innovative startups", as defined in Article 25 of the same Law Decree. Recognised as an alternative source of funding, able to increase industrial productivity, the competitiveness of the domestic economy and the creation of employment, the use of equity crowdfunding has been extended to all SMEs, through the Law n.232/2016 (Article 1, sub-paragraph 70) and also to SMEs established in the form of limited liability companies, with the Decree Law n. 50/2017 (Article 57, sub-paragraph 1).

Crowdfunding regulation has been further expanded by the Legislative Decree n.129 dated 3 August 2017 implementing the Directive 2014/65/UE (MiFID II).

Under the current law, the management of equity crowdfunding portals in Italy can be carried out by two types of subjects [2]. 
(1) "ipso iure" managers, that is to say, authorised entities (such as banks, national and European investment companies) subject to MiFID rules;

(2) other legal entities expressly authorised by CONSOB.

Regulating the equity-based crowdfunding

Since 2016, Italian crowdfunding platforms can offer to the investors:

(1) shares or units (quotas) of the equity capital of startups and SMEs;

(2) shares or units (quotas) of Collective Investment Undertakings (CIUs) or other companies investing at least $70 \%$ in startups and SMEs.

All portals' managers, other than banks and financial intermediaries, have to register with the ordinary section of the Register of the portals' managers, published on CONSOB website. Authorised entities are instead enrolled in a special section of CONSOB Register.

As said above, portals' managers must comply with the strict integrity and professionalism requirements laid down by CONSOB Regulation (Articles 8 and 9). Platforms must also follow specific rules of conduct and operate with diligence, fairness and transparency. They must ensure equal treatment of investors and protect their interests. Article 13 of CONSOB Regulation provides for heavy rules on conflicts of interest which could arise in the management of the platform and in the offer from the portal manager of his own financial instruments (self-placement). Article 20 bis, provides for whistleblowing procedures.

To ensure a more adequate level of investors protection and increase the reliability of the service provided by portals' managers, CONSOB Regulation lays down a set of transparency and disclosure requirements that platforms must fulfil to allow potential investors to make an informed decision on the investment.

Articles 14, 15 and 16, require managers to supply "in a brief and easily comprehensible form, even by the use of multimedia techniques" a set of information on portals management, on the investment risks in financial instruments through portals, on the offers, and so on. In addition, sub-paragraph 2 (art.15), provide for retail investors (other than the categories referred to in point j) of Article 2) a special protection regime under which the latter, before subscribing any offer through online portals, must make a "conscious investment path" in order to understand the high risks involved therein. In particular, retail investors must: (i) demonstrate that they have actually seen the information about investor education with regard to equity crowdfunding, available on CONSOB website; (ii) must complete a questionnaire indicating their level of understanding of investment characteristics and risks and (iii) must declare to be able to financially support the potential losses of the investment.

According to Article 25 (sub-paragraph 2), investors can revoke their adhesion to the offer in the following two cases:

(1) the presence of relevant material mistake concerning the information given on the portal; and

(2) the emergence of any new fact which could influence the decision on the investment.

Such Revocation Right must be exercised within seven days from the date when the new fact occurred or the new information was communicated to the investor.

Investors are entitled to withdraw from the company or to sell the participation instruments, within three years from the conclusion of the offer if the controlling shareholders (directly or indirectly) transfer the control of the company to third parties (Art. 24, subparagraph 1).

Following the due diligence duties, platforms must provide detailed information on strategies for project selection. For portals' managers that violate the established rules, the 
JEPP

10,2

Regulation proposes heavy penalties that can reach $€ 25,000$ in addition to the suspension of the portal manager from one to four months or the radiation from the register. To operate in the Italian market foreign platforms must be authorised by CONSOB and operate under its regulation.

Italian regulation makes a distinction (rely upon the self-certification) between professional investors, as defined in point (j) of Article 2, and retail investors. These latter are subject to a different protection regime requiring an appropriateness test made by platforms or, in the alternative, by banks or investment firms that receive the orders. Investors must read the financial investor education material published on CONSOB website and state their awareness about the risk of loss of their entire investment.

There are no investment limits for investors. However, an exemption from all TUF rules and CONSOB regulation is provided for investments "below the threshold" i.e. single investment less than $€ 500$ (for natural persons) or $€ 5,000$ (for legal entities), and annual total investment less than $€ 1,000$ (for natural persons) or $€ 10,000$ (for legal entities).

Lending-based crowdfunding has been regulated only recently in Italy through the Bank of Italy resolution n.584, comes into force the 1 January 2017. To carry out lending activity, platforms have to apply for the Payment Service Provider (PSP) or Electronic Money Issuer (EMI) license granted by the Bank of Italy. As an alternative, they can apply for passport the license granted by another European supervisory authority in the relevant home member state. Lending platforms must enrol in the Financial Intermediaries' Register (the PSPs' Register) or in the EMIs' Register (Art. 106 of TUB). As in most other European countries, Italian Regulator does not provide for a specific regulation for donation- and reward-based crowdfunding. Therefore, platforms do not need to be licensed and are not monitored by the CONSOB Authority.

\subsection{Spain}

To respond to the companies' traditional dependence on bank financing, the Spanish government developed at the end of February 2014 a draft law on the "Promotion of Corporate Financing." The Ley de Fomento de la Financiación Empresarial (Law 5/2015, also called LEFE), regulating both equity and peer-to-peer lending crowdfunding, came into force on 29 April 2015. Donation and reward-based crowdfunding are not regulated under the existing legislation. LEFE law (Articles 46 to 93) has introduced a new category of intermediary in the crowdfunding market: the participatory financing platforms (Plataformas de Financiación Participativa, or PFP).

PFP platforms are not investment firms or credit institutions but companies whose activity is to bring investors (individuals or legal entities who provide funding in exchange for a monetary compensation) into contact with promoters (natural or legal persons who request financing on their own behalf to allocate it to a participatory financing project), in a professional manner and through websites or other electronic means.

Participatory crowdfunding platforms may offer the following instruments (Art. 50):

(1) transferable securities such as bonds, ordinary and preferential shares, and other securities representing the capital in accordance with the Act 24/1988 of 28 July, on the Securities Market (Ley de Mercado de Valores-LMV);

(2) participations in limited liability companies provided that the company's by-laws ensure their transferability;

(3) loans, including participating loans.

To operate as investment firms or credit institutions, and offering investment advice or process payments, platforms must apply for a license as hybrid payment institutions (Art. 52). 
According to Article 46, crowdfunding platforms must be authorised by the Spanish Securities Market Commission (Comisión Nacional del Mercado de Valores-CNMV) and registered in its official registry. To be enrolled in CNMV registry, platforms must meet high capital and financial requirements established by the LFFE (Articles 55 and 56). Moreover, lending-based platforms are subject to a mandatory and binding report by the Bank of Spain.

LFFE establishes professional and integrity requirements for platforms which must have an internal code of conduct that addresses potential conflicts of interest.

Moreover, platforms managers must have a good professional reputation, possess appropriate knowledge and experience, and operate in accordance with the principles of neutrality, diligence and transparency and in accordance with the best interest of their clients (Art. 60).

Investing through crowdfunding brings potentially high risks also related to the information asymmetry between investors and projects promoters. Spanish Law on crowdfunding provides a set of specific measures to protect investors (Art. 81-88).

Platforms should have their websites well up to date on the specific risks associated with the investment and conflicts of interest that might affect them. They are also obliged to ensure the completeness of the published information (in accordance with the legal provisions) and publish all other relevant information in their possession about the project or the promoters (art. 71). Promoters will be responsible to the investors for the provided information (art. 73).

Platforms must properly verify the promoters' identity and evaluate with due diligence the admission of financing projects and their adaptation to the established requirements (art. 66). In line with Article 75, in crowd lending projects platforms can hide the identity of the promoter on condition that investors are given access to this information at any stage prior to the effective contribution of funds.

Article 83 on pre-investment information requirements, establishes that, before investing in a project, platforms must guarantee that non accredited investors receive and accepts a specific communication in which they are warned, in a clear and understandable way of the following circumstances:

(1) projects are not subject to authorisation or supervision by the National Securities Market Commission or the Bank of Spain and the information provided by the promoter has not been reviewed by them. This also applies to securities issue;

(2) the existence of investment related risks (total or partial loss of investment and interest payments, rarity of dividends and lack of liquidity);

(3) the invested capital is not guaranteed by the Depositors and Investors Guarantee Fund;

(4) any other circumstance determined by the Spanish securities market regulator.

This obligation shall not be required when the investor is accredited.

Article 85 provides that the activity carried out by the investment platforms and the relations between promoters and investors will be subject, with some adaptations, to the regulations on investors and users' protections well as to the mechanisms on protection of financial services clients, and to what is established in articles 29 and 30 of Law 44/2002, of November 22, of measures for the reform of the financial system. For all investment platforms, Article 86 demands the application of the Consumer Law.

Platforms cannot publish projects in which consumers request a loan or credit with mortgage guarantee and they have to limit the risk of investors taking on too much debt (Articles 87 and 88). 
JEPP

10,2

As laid down in chapter VI (art. 89-93) of LEFE, platforms are under the supervision, inspection and sanction of the CNMV, with the participation of the Bank of Spain in the case of lending-based crowdfunding. For serious or very serious infringements (as defined in Article 92), fines of variable amounts are envisaged as well as the suspension or revocation of the authorisation.

Spain distinguishes between accredited (or professional) investors and non-accredited ones (retail investors).

Accredited investors are:

(1) natural and legal persons who are considered professional clients (definition and classification according to the article 78 bis of the LMV Law 24/1988 of July 28);

(2) entrepreneurs who possess at least two of the following characteristics: (i) total assets equal to or greater than $€ 1$ million; (ii) an annual turnover of $€ 2$ million or more; (iii) own resources equal to or higher than $€ 300,000$;

(3) individuals with annual revenues of more than $€ 50,000$ or financial asset of more than $€ 100,000$, or who require to be considered as first-time accredited investors, expressly waiving their treatment as non-accredited investors. The acceptance of that request is conditioned by the appropriate evaluation of the investor's experience and knowledge, and by the guarantee that it can make its own investment Resolutions and understands its risks;

(4) legal persons and SMEs (PYMES) not mentioned in the previous sections, who expressly request to be treated as accredited investors.

Individuals and legal persons certifying the hiring of the financial advice service on the financing instruments of the platform by an authorized investment firm can also be considered as an accredited investor. Accredited investors of points three and four who do not provide financing to a project on the platform within a period of twelve months, will lose the status of accredited investors. In the same way, they will lose this status when they request it in writing. Accredited investors are not subject to any specific investment limits but are exposed to greater risks and enjoy lesser protection.

Non-accredited investors cannot invest or commit to invest over $€ 3,000$ in the same project managed by the same platform or more than $€ 10.000$ over a period of twelve months in projects published by the same platform (art. 82).

According to the article 84, non-accredited investors who require to be considered as accredited investors, before acting in this capacity for the first time, have to provides a statement evidencing that they have been warned about the greater risks and lesser protection and that their total investment in the last twelve months in projects published by all platforms not exceed the threshold of $€ 10,000$.

To operate in Spain, foreign crowdfunding platforms shall comply with the LFFE and CNMV regulations.

\section{Key findings and discussion}

In the following section, we evaluate the different investors' protection systems analysed above and summarised in Table 2.

From the analysis of the existing body of norms on ECF investors emerge two typologies of country regulations, restrictive and not restrictive; the firsts discourage investors and overprotect them, the latter encourages investors, protecting investors in an adequate manner from the risk of investments. The restriction of regulation is analysed through four factors that impact the level of investor protection: investment requirements, reliability, suitability and transparency and disclosure (Table 3). Investment requirements are given by the size of the 


\begin{tabular}{|c|c|c|c|c|c|}
\hline & Reliability & $\begin{array}{l}\text { Investment } \\
\text { requirements }\end{array}$ & Suitability & $\begin{array}{l}\text { Transparency and } \\
\text { disclosure }\end{array}$ & $\begin{array}{l}\text { equity-based } \\
\text { crowdfunding }\end{array}$ \\
\hline \multirow[t]{2}{*}{ UK } & \multirow[t]{2}{*}{$\begin{array}{ll}\text { (1) Sophisticated } \\
\text { investors } \\
\text { (2) High-net-worth } \\
\text { investors } \\
\text { (3) Unsophisticated } \\
\text { investors }\end{array}$} & \multirow{2}{*}{$\begin{array}{l}\text { (1) No limits for } \\
\text { sophisticated and } \\
\text { net-worth investors } \\
\text { (2) Unsophisticated } \\
\text { investors cannot } \\
\text { invest more than } \\
10 \% \text { of their net } \\
\text { investable assets } \\
\text { within a 12-month } \\
\text { period }\end{array}$} & \multirow{2}{*}{$\begin{array}{l}\text { Investors are required } \\
\text { to self-certify their } \\
\text { belonging to one of } \\
\text { the investors' } \\
\text { categories. Platforms } \\
\text { must carry out a } \\
\text { screening process to } \\
\text { identify the non- } \\
\text { sophisticated } \\
\text { investors }\end{array}$} & \multirow{2}{*}{$\begin{array}{l}\text { Platforms must } \\
\text { provide sufficient } \\
\text { information about } \\
\text { the nature and risks } \\
\text { of crowdfunding } \\
\text { investments (in a } \\
\text { fair, clear and not } \\
\text { misleading manner), } \\
\text { to allow investors to } \\
\text { make an informed } \\
\text { investment decision }\end{array}$} & 251 \\
\hline & & & & & \\
\hline Germany & $\begin{array}{l}\text { No restriction on } \\
\text { investor type }\end{array}$ & $\begin{array}{l}\text { (1) No limits for } \\
\text { corporate entities } \\
\text { (2) Individual } \\
\text { investment limit of } € \\
25,000 \text { per investor } \\
\text { per year }\end{array}$ & $\begin{array}{l}\text { Investors must } \\
\text { confirm the } \\
\text { understanding of the } \\
\text { information sheet } \\
\text { (containing the } \\
\text { warning notice about } \\
\text { the risks associated } \\
\text { with the investment } \\
\text { and the potential total } \\
\text { loss of the invested } \\
\text { money) with a } \\
\text { signature on it }\end{array}$ & $\begin{array}{l}\text { Platforms providing } \\
\text { investment advice } \\
\text { must provide an } \\
\text { investment } \\
\text { information sheet } \\
\text { (VIB) to potential } \\
\text { investors, in good } \\
\text { time prior to } \\
\text { purchase of the } \\
\text { investment }\end{array}$ & \\
\hline France & $\begin{array}{l}\text { No restriction on } \\
\text { investor type }\end{array}$ & No limits & $\begin{array}{l}\text { Registration and } \\
\text { suitability test for } \\
\text { investors which must } \\
\text { prove that they have } \\
\text { been warned of and } \\
\text { expressly accepted } \\
\text { the risks }\end{array}$ & $\begin{array}{l}\text { Platforms must } \\
\text { publish on their } \\
\text { website a set of } \\
\text { mandatory } \\
\text { information in an } \\
\text { intelligible and } \\
\text { visible manner }\end{array}$ & \\
\hline Italy & $\begin{array}{ll}\text { (1) } & \text { Professional } \\
\text { investors } \\
\text { (2) } \\
\text { Retail investors }\end{array}$ & $\begin{array}{l}\text { No limits } \\
\text { Exemption from } \\
\text { appropriateness test } \\
\text { for investments } \\
\text { below the following } \\
\text { thresholds } \\
\text { (1) single investment: } \\
€ 500 \text { (for natural } \\
\text { persons) and } € 5.000 \\
\text { (for legal entities) } \\
\text { (2) annual total } \\
\text { investment: } € 1.000 \\
\text { (for natural persons) } \\
\text { and } € 10.000 \text { (for legal } \\
\text { entities) }\end{array}$ & $\begin{array}{l}\text { Appropriateness test } \\
\text { for retail investors } \\
\text { which must read the } \\
\text { financial investor } \\
\text { education material } \\
\text { published on } \\
\text { CONSOB website and } \\
\text { state their awareness } \\
\text { about the risk of loss } \\
\text { of their entire } \\
\text { investment (conscious } \\
\text { investment path) }\end{array}$ & $\begin{array}{l}\text { For each offer, } \\
\text { platforms must } \\
\text { supply, in a brief and } \\
\text { easily } \\
\text { comprehensible } \\
\text { form, information on } \\
\text { investment risks, } \\
\text { issuer, the financial } \\
\text { instruments offered, } \\
\text { and so on }\end{array}$ & $\begin{array}{r}\text { Table } 2 . \\
\text { Key factors of } \\
\text { investors regulation in } \\
\text { the analysed countries }\end{array}$ \\
\hline
\end{tabular}


JEPP

10,2

\begin{tabular}{llll}
\hline Reliability & $\begin{array}{l}\text { Investment } \\
\text { requirements }\end{array}$ & Suitability & $\begin{array}{l}\text { Transparency and } \\
\text { disclosure }\end{array}$
\end{tabular}

Spain (1) Accredited For non-accredited Investors are required Platforms must
investors investors: investment to self-certified their

(2) Non-accredited limit of $€ 3,000$ per experience and project up to $€ 10.000 \quad$ knowledge (a test is investors per year on the same platform not due). Platforms must properly identify their clients and verify that they are aware about the risks

inform investors about the risks and the potential conflicts of interest. They must warn the investors, in a clear and understandable way, that platforms are not investment firms or credit institutions, and projects are not subject to authorization or supervision

Table 2.

Source(s): Authors' elaboration

\begin{tabular}{|c|c|c|}
\hline & Restricted & Not restricted \\
\hline Reliability & $\begin{array}{l}\text { Classification of investor } \\
\text { type }\end{array}$ & No classification of investor type \\
\hline Investment requirements & Thresholds of investment & $\begin{array}{l}\text { Thresholds of investment for non-professional } \\
\text { investors }\end{array}$ \\
\hline Suitability & Suitability test & Self-certifications \\
\hline $\begin{array}{l}\text { Transparency and } \\
\text { disclosure }\end{array}$ & $\begin{array}{l}\text { Specific obligations and } \\
\text { norms }\end{array}$ & No specific obligation and norms \\
\hline
\end{tabular}

investment, considering as restrictive regulations those that provide thresholds of investment. The reliability considers the classification of investor type: a not restrictive regulation does not establish categories. The suitability is referred to the type of test required to evaluate the awareness of investment: self-certifications are not considered characteristics of restricted regulations, while tests are typical of restricted regulations. Transparency and disclosure of information are referred to documents that make investors better informed: more documents mean protection and encouragement, fewer documents reveal discouragement and make investors uninformed. This factor is evaluated taking into account indirect regulations, that is obligations and norms for crowdfunding platforms and for companies.

From the analysis emerges (Table 4):

(1) The UK has a not restrictive regulation for investors, neither for other actors of the crowdfunding system. However, to ensure an adequate level of crowdfunding investors protection, regulation subdivides investors into three categories (sophisticated, highnet-worth and unsophisticated). Particularly, to become accredited investors it is sufficient to have worked at least two years in the private equity sector or to have large assets. For them, there are no limits of investments or restricted suitability requirements (they have to self- certify their belonging category). Small restrictions are only for unsophisticated investors that can invest less than $10 \%$ of their assets and 
are subject to suitability screening. This not restrictive regulation is compensated by some transparency and disclosure activities planned for platforms that must provide information about the risk and nature of crowdfunding to make investors informed. In general, norms are often at the discretion of the single platforms, that have not obligations on due diligence procedures and for this reason, they do not perceive regulation as inadequate (Appendix, Figure A1). The absence of obligations could create a fragmentation of norms between different platforms, disinforming and confusing investors. However, this type of regulation produces in Europe large volumes of crowdfunding transactions (Figure 1).

(2) Germany presents a punctual, but not restrictive regulation for investors. In fact, there is no categorisation for investors (there is no classification among investors), no investment limits (except if you are a non-corporate investor) or a suitability test (you must sign an information sheet stating that you are capable/suitable for absorbing any loss). However, to ensure their transparency, availability of information and protection, control and monitoring activities are established with respect to platforms and companies. In fact, the former must ascertain the suitability of the installer according to the provisions of the "Securities Trading Act or the Financial Investment Broker Ordin" while the companies are required to provide due information under civil liability. Consequently, German regulation offers a good degree of protection for investors but platforms perceive too restrictive regulations and very unstable for them (Appendix, Figures (A1 and A2). That climate of dissatisfaction ensures moderate volumes of crowdfunding transactions (Figure 1).

(3) France presents an investor-oriented approach based on an equilibrium between protection and encouragement. It prefers no define a distinction between investors (i.e. expert or no expert investors), no establish restricted limitation in investment amount, providing, however, a registration and suitability test to prove that investors have been warned of and are aware of the risks.

At the same time, platforms are subjected to publish mandatory information for the investment security and companies are responsible for the completeness, accuracy and the nature of the information provided. Even though France, like Germany, requires a high level of due diligence for platforms, these do not perceive regulation as inadequate and restrictive (Appendix, Figure A1). In France regulation has had a positive impact on volumes of crowdfunding transactions because from 2014-2015, years in which the government enacts regulations, volumes increased substantially (Figure 1).

(4) Italy presents a restricted regulation; it is a paternalistic country and prefers overprotecting investors. Regulations impose a distinction between professional and

\begin{tabular}{|c|c|c|c|c|c|c|c|c|c|c|}
\hline & \multicolumn{2}{|c|}{ UK } & \multicolumn{2}{|c|}{ Germany } & \multicolumn{2}{|c|}{ France } & \multicolumn{2}{|c|}{ Italy } & \multicolumn{2}{|c|}{ Spain } \\
\hline & Restr & restr & Restr & restr & Restr & restr & Restr & restr & Restr & restr \\
\hline Reliability & $\mathrm{X}$ & & $\mathrm{X}$ & & & X & $\mathrm{X}$ & & X & \\
\hline $\begin{array}{l}\text { Investment } \\
\text { requirements }\end{array}$ & $\mathrm{X}$ & & & $\mathrm{X}$ & & $\mathrm{X}$ & & $\mathrm{X}$ & $\mathrm{X}$ & \\
\hline Suitability & & $\mathrm{X}$ & & $\mathrm{X}$ & & $\mathrm{X}$ & $\mathrm{X}$ & & & $\mathrm{X}$ \\
\hline $\begin{array}{l}\text { Transparency and } \\
\text { disclosure }\end{array}$ & & X & $\mathrm{X}$ & & $\mathrm{X}$ & & $\mathrm{X}$ & & $\mathrm{X}$ & \\
\hline
\end{tabular}

Source(s): Authors' elaboration

Regulating the equity-based crowdfunding 
JEPP

10,2

retail investors, fixing a test for investors who annually invest sums bigger than $€ 1,000$ (for natural persons) and $€ 10,000$ (for legal entities). There are not restrictive investment limits. Furthermore, investors have to read the educational material published on the Consob website to confirm their awareness about the risk. Platforms must supply information on investments and on companies and are liable for damages to customers. A bureaucratised context discourages crowdfunding actors, particularly investors, also if they are well protected. In fact, regulations fixed by Italian regulatory authorities are not able to encourage investors, neither companies. Figure 1 shows that, despite the introduction of tailored rules and norms, crowdfunding transactions are very few.

(5) Spain has a regulation partially restrictive. On the one side, it establishes a distinction between investor type (accredited and non-accredited), fixing investment limits for nonaccredited and controls ("an appropriate evaluation") for accredited investors. On the other side, national regulation or platforms do not determine a suitability test for investors. However, platforms should warn investors about the risks, in a clear way, and are obligated to ensure completeness of information, evaluating with due diligence financial projects. A high level of reliability and investors' requirements, offset by a low level of suitability is sufficient to guarantee a moderate volume of crowdfunding transactions (Figure 1). Considering the economic Spanish crisis, institutions have applied specific regulations trying to not obstruct crowdfunding, a valid alternative to traditional forms of fundraising.

The European Commission report (2017) provides interesting results to conclude our analysis. The Commission survey has provided a measure of investors' perceptions of regulatory aspects of crowdfunding in Europe, on the basis of the level of awareness, trust and effectiveness. In particular, from the analysed data an unawareness of the source of regulations still comes out (see Appendix Figure A2). Despite the 51,27\% know who is the regulator, one in four respondents do not know how the market is regulated. This result is due to the fragmentation of regulations: some norms are established by institutions, other by platforms. In addition, norms differ country by country considerately: this does not permit a German investor to finance an Italian firm easily. Investors declare regulations influence trust in crowdfunding but they do not influence the size of the investment (see Appendix Figure A3). It means are not necessary restriction about investment requirements, rather could be useful to provide disclosure and transparency.

\section{Conclusion and implications}

This study highlights how the regulatory aspect is important to attract investors, nevertheless, the protection of investors may enhance or constrain the creation and development of firms ( $\mathrm{La}$ Porta et al., 2000, 2002; Glaeser et al., 2001). Strong protection reduces the freedom of investors in choosing projects and managing the business (Hamilton, 2000; Hundley, 2001; Moskowitz and Vissing-Jørgensen, 2002), concomitantly delay the funding of startups or other firms (Hyytinen and Takalo, 2003). In certain economies, entrepreneurs have difficulties finding financiers, so much so that the issue plays an increasingly important role in the policy agenda of local, national and international governmental institutions (Block et al., 2018). They should encourage new entrepreneurial financing instruments, on the one hand facilitating young businesses in raising capital, on the other hand not hampering investors. To foster investors means avoiding stringent requirements, preferring norms and rules on transparency and disclosure. Or at very least institutions might not apply rules that limit entrepreneurial freedom when capitals are designed to small companies.

To conclude, the paper shows that different regulations can produce different volumes of crowdfunding transactions. The winning model seems to be that of the UK, Germany and 
France, less restrictive than others, but at the same time very attentive to transparency and disclosure.

The comparison between countries is appropriate to addressed investors, policymakers and intermediaries:

(1) investors in orienting themselves between different crowdfunding regulations and by enabling them to evaluate levels of protection;

(2) policymakers and intermediaries in aligning and orchestrating rules and norms, avoiding to disorient and discourage non-sophisticated investors and young businesses.

Furthermore, it also appears useful to adopt, both at the country level and at the European level, a collaborative approach between institutions and the market to regulate an emergent sector as ECF (Nehme, 2018). In light of our findings, the promotion of new forms of financing must be regulated by appropriate rules without discouraging vulnerable actors of the crowdfunding system, that is young funders and young founders. This means avoiding to adopt restrictions in terms of requirements or to bureaucratise the process excessively. Instead, it would be useful to communicate, direct and inform about risks and procedures. In addition, this study also considers the effect of the indirect regulatory approach towards investors. In fact, policymakers of the five analysed countries have introduced rules to regulate ECF platforms. These rules represent an incentive or an obstacle for the investor. Also, in this case, an appropriate combination of advice and information allows investors in taking advantage of more efficient ECF platforms. The paper has some limitations. The analysis involves only a few European countries and investigates only one category of crowdfunding actors: investors. However, it provides interesting insights for future research, which could measure the effect of regulations on transaction volumes, analyse and compare regulations addressed to the platforms or deepen how these restrictions impact on entrepreneurship.

\section{Notes}

1. Only for lending-based crowdfunding, the French regulation set up a limit for lenders of $€ 2,000(€$ 5,000 for interest-free loan) per project and per year.

2. Source: See Article 50 quinquies, sub-paragraph 2, of TUF.

\section{References}

Acemoglu, D., Johnson, S. and Robinson, J.A. (2005), "Institutions as a fundamental cause of long-run growth", Handbook of Economic Growth, Vol. 1, pp. 385-472.

Agrawal, A., Catalini, C. and Goldfarb, A. (2014), "Some simple economics of crowdfunding", Innovation Policy And the Economy, Vol. 14 No. 1, pp. 63-97.

Ahlers, G.K., Cumming, D., Günther, C. and Schweizer, D. (2015), "Signaling in equity crowdfunding", Entrepreneurship: Theory and Practice, Vol. 39 No. 4, pp. 955-980.

Autio, E. and Acs, Z. (2010), "Intellectual property protection and the formation of entrepreneurial growth aspirations", Strategic Entrepreneurship Journal, Vol. 4 No. 3, pp. 234-251.

Bade, M. (2018), "Bargaining over crowdfunding benefits", Journal of Entrepreneurship and Public Policy, Vol. 7 No. 2, pp. 166-177.

Belleflamme, P., Lambert, T. and Schwienbacher, A. (2013), "Individual crowdfunding practices", Venture Capital, Vol. 15 No. 4, pp. 313-333.

Belleflamme, P., Lambert, T. and Schwienbacher, A. (2014), "Crowdfunding: tapping the right crowd", Journal of Business Venturing, Vol. 29 No. 5, pp. 585-609.

Block, J.H., Colombo, M.G., Cumming, D.J. and Vismara, S. (2018), "New players in entrepreneurial finance and why they are there", Small Business Economics, Vol. 50 No. 2, pp. 239-250.

Regulating the equity-based crowdfunding

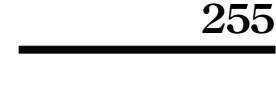


JEPP

10,2

Brummer, C. (2011), "Territoriality as a Regulatory Technique: Notes from the Financial Crisis", University of Cincinnati Law Review, Vol. 79 No. 2, pp. 499-526.

Cable, A.J. (2014), "Mad money: rethinking private placements", Wash. \& Lee L. Rev., Vol. 71, p. 2253.

Casamatta, C. and Haritchabalet, C. (2007), "Experience, screening and syndication in venture capital investments", Journal of Financial Intermediation, Vol. 16 No. 3, pp. 368-398.

Cicchiello, A.F. (2019a), "Harmonizing the crowdfunding regulation in Europe: need, challenges, and risks", Journal of Small Business and Entrepreneurship, pp. 1-22, doi: 10.1080/08276331.2019. 1603945.

Cicchiello, A.F. (2019b), "Building a crowdfunding-based ecosystem for entrepreneurship in Europe: the role of public policy", Journal of Entrepreneurship and Public Policy, Vol. 8 No. 3, pp. 297-318.

Cicchiello, A.F., Battaglia, F. and Monferra, S. (2019), "Crowdfunding tax incentives in Europe: a comparative analysis", The European Journal of Finance, Vol. 25 No. 18, pp. 1856-1882, doi: 10. 1080/08276331.2019.1603945.

Colombo, M.G., Franzoni, C. and Rossi-Lamastra, C. (2015), "Internal social capital and the attraction of early contributions in crowdfunding", Entrepreneurship: Theory and Practice, Vol. 39 No. 1, pp. 75-100.

Cosh, A., Cumming, D. and Hughes, A. (2009), "Outside enterpreneurial capital", The Economic Journal, Vol. 119 No. 540, pp. 1494-1533.

Cumming, D. and Hornuf, L. (2018), The Economics of Crowdfunding, Palgrave Macmillan, London, pp. 1-279.

European Commission report (2017), "Identifying market and regulatory obstacles to cross-border development of crowdfunding in the EU. Final report December 2017", available at: https:/ec. europa.eu/info/sites/info/files/171216-crowdfunding-report_en.pdf.

Financial Conduct Authority (2017), Conduct of Business Sourcebook (COBS), 4.7.7, COBS Contents, pp. 4.7.10.

Fisch, J.E. (1998), "Can Internet offerings bridge the small business capital barrier”, Journal of Small and Emerging Business Law, Vol. 2, p. 57.

Frankel, T. (1998), "The Internet, securities regulation, and theory of law", 73 Chicago-Kent Law Review, Vol. 73 No. 17, pp. 1319-1354.

Glaeser, E., Johnson, S. and Shleifer, A. (2001), "Coase versus the coasians", Quarterly Journal of Economics, Vol. 116 No. 3, pp. 853-899.

Hamilton, B.H. (2000), "Does entrepreneurship pay? An empirical analysis of the returns to selfemployment", Journal of Political Economy, Vol. 108 No. 3, pp. 604-631.

Hart, S.L. and Milstein, M.B. (2003), "Creating sustainable value", Academy of Management Perspectives, Vol. 17 No. 2, pp. 56-67.

Heminway, J.M. (2014), "Investor and market protection in the crowdfunding era: disclosing to and for the crowd", Vermont Law Review, Vol. 38, p. 827.

Heminway, J (2016), "Securities crowdfunding and investor protection", CESifo DICE Report, ISSN, 1613-6373, Vol. 14 No. 2, pp. 11-15.

Hornuf, L. and Schwienbacher, A. (2016), "15 Crowdinvesting: angel investing for the masses?", Handbook of Research on Business Angels, p. 381.

Hornuf, L. and Schwienbacher, A. (2017), "Should securities regulation promote equity crowdfunding?", Small Business Economics, Vol. 49 No. 3, pp. 579-593.

Hundley, G. (2001), "Why and when are the self-employed more satisfied with their work?", Industrial Relations: A Journal of Economy and Society, Vol. 40 No. 2, pp. 293-316.

Hyytinen, A. and Takalo, T. (2003), "Investor protection and business creation”, Bank of Finland Discussion Paper, 17. 
Kempster, S. and Cope, J. (2010), "Learning to lead in the entrepreneurial context", International Journal of Entrepreneurial Behavior and Research, Vol. 16 No. 1, pp. 5-34.

Klöhn, L., Hornuf, L. and Schilling, T. (2016), "The regulation of crowdfunding in the German small investor protection act: content, consequences, critique, suggestions", European Company Law, Vol. 13 No. 2, pp. 56-66.

La Porta, R., Lopez-de-Silanes, F., Shleifer, A. and Vishny, R. (2000), "Investor protection and corporate governance", Journal of Financial Economics, Vol. 58 Nos 1-2, pp. 3-27.

La Porta, R., Lopez-de-Silanes, F., Shleifer, A. and Vishny, R. (2002), "Investor protection and corporate valuation”, The Journal of Finance, Vol. 57 No. 3, pp. 1147-1170.

Lee, E. (2019), "Equity crowdfunding in Hong Kong: potential, challenges and investor protection", Journal of Corporate Law Studies, Vol. 19 No. 2, pp. 277-302.

Leone, D. and Schiavone, F. (2018), "Innovation and knowledge sharing in crowdfunding: how social dynamics affect project success", Technology Analysis and Strategic Management, Vol. 31 No. 7, pp. 803-816.

Leone, D., Schiavone, F. and Dezi, L. (2018), "Post-campaign operational problems hindering promised rewards in crowdfunding projects", Journal of Innovation Economics Management, No. 2, pp. 173-194.

Levie, J. and Autio, E. (2011), "Regulatory burden, rule of law, and entry of strategic entrepreneurs: an international panel study", Journal of Management Studies, Vol. 48 No. 6, pp. 1392-1419.

Mollick, E. (2014), "The dynamics of crowdfunding: an exploratory study", Journal of Business Venturing, Vol. 29 No. 1, pp. 1-16.

Moritz, A. and Block, J.H. (2016), "Crowdfunding: a literature review and research directions", in Brüntje, D. and Gajda, O. (Eds), Crowdfunding in Europe: State of the Art in Theory and Practice, Springer, Cham, pp. 25-53.

Moskowitz, T.J. and Vissing-Jørgensen, A. (2002), "The returns to entrepreneurial investment: a private equity premium puzzle?", The American Economic Review, Vol. 92 No. 4, pp. 745-778.

Müllerleile, T. and Joenssen, D.W. (2015), "Key success-determinants of crowdfunded projects: an exploratory analysis", Data Science, Learning by Latent Structures, and Knowledge Discovery, Springer, Berlin, Heidelberg, pp. 271-281.

Nehme, M. (2018), "Regulating crowd equity funding-the why and the how", Journal of Law and Society, Vol. 45 No. 1, pp. 116-135.

Pesok, J. (2014), "Crowdfunding: a new form of investing requires a new form of investor protection", Dartmouth LJ, Vol. 12, p. 146.

Pierce-Wright, C.H. (2016), "State equity crowdfunding and investor protection", Washington Law Review, Vol. 91, p. 847.

Porter, M.E. and Kramer, M.R. (2006), "The link between competitive advantage and corporate social responsibility", Harvard Business Review, Vol. 84 No. 12, pp. 78-92.

Ripken, S.K. (2015), "Paternalism and securities regulation", Stan. JL Bus. \& Fin., Vol. 21, p. 1.

Schwartz, A. (2018), "The gatekeepers of crowdfunding”, Washington and Lee Law Review, Vol. 75, p. 885.

Schwienbacher, A. and Larralde, B. (2012), "Crowdfunding of small entrepreneurial ventures", in Cumming, D. (Ed.), The Oxford Handbook of Entrepreneurial Finance, Oxford University Press, Oxford, NY, pp. 369-391.

Shane, S. and Cable, D. (2002), "Network ties, reputation, and the financing of new ventures", Management Science, Vol. 48 No. 3, pp. 364-381.

Ward, C. and Ramachandran, V. (2010), "Crowdfunding the next hit: microfunding online experience goods", Workshop on Computational Social Science and the Wisdom of Crowds at NIPS2010, pp. 1-5.
Regulating the equity-based crowdfunding 
JEPP

10,2

World Bank (2013), “Crowdfunding's potential for the developing world”, available at: http://www. infodev.org/infodev-files/wb-crowdfundingreport-vl2.pdf.

Zhang, B., Ziegler, T., Garvey, K., Ridler, S., Yerolemou, N. and Hao, R. (2017), Entrenching InnovationThe 4th UK Alternative Finance Industry Report, Cambridge Centre for Alternative Finance, Cambridge.

Ziegler, T., Shneor, R., Garvey, K., Wenzlaff, K., Yerolemou, N., Hao, R. and Zhang, B. (2018), Expanding Horizons: The 3rd European Alternative Finance Industry Report.

\section{Further reading}

Agarwal, R. and Shah, S.K. (2014), "Knowledge sources of entrepreneurship: firm formation by academic, user and employee innovators", Research Policy, Vol. 43 No. 7, pp. 1109-1133.

Andries, P. and Debackere, K. (2007), "Adaptation and performance in new businesses: understanding the moderating effects of independence and industry", Small Business Economics", Vol. 29 Nos 1-2, pp. 81-99.

Autio, E., Pathak, S. and Wennberg, K. (2013), "Consequences of cultural practices for entrepreneurial behaviors", Journal of International Business Studies, Vol. 44 No. 4, pp. 334-362.

Autio, E., Kenney, M., Mustar, P., Siegel, D. and Wright, M. (2014), "Entrepreneurial innovation: the importance of context", Research Policy, Vol. 43 No. 7, pp. 1097-1108.

Barber, B.M. and Odean, T. (2002), "Online investors: do the slow die first?", Review of Financial Studies, Vol. 15 No. 2, pp. 455-488.

Bharadwaj, A., El Sawy, O.A., Pavlou, P.A. and Venkatraman, N. (2013), "Digital business strategy: toward a next generation of insights", MIS Quarterly, pp. 471-482.

Boettke, P.J. and Coyne, C.J. (2009), “Context matters: institutions and entrepreneurship”, Foundations and Trends ${ }^{\circledR}$ in Entrepreneurship, Vol. 5 No. 3, pp. 135-209.

Burtch, G., Ghose, A. and Wattal, S. (2013), "An empirical examination of the antecedents and consequences of contribution patterns in crowd-funded markets", Information Systems Research, Vol. 24 No. 3, pp. 499-519.

Cummings, M.E., Rawhouser, H., Vismara, S. and Hamilton, E.L. (2020), "An equity crowdfunding research agenda: evidence from stakeholder participation in the rulemaking process", Small Business Economics, Vol. 54, pp. 907-932.

Dean, T.J. and McMullen, J.S. (2007), "Toward a theory of sustainable entrepreneurship: reducing environmental degradation through entrepreneurial action", Journal of Business Venturing, Vol. 22 No. 1, pp. 50-76.

Drori, I., Honig, B. and Wright, M. (2009), "Transnational entrepreneurship: an emergent field of study", Entrepreneurship: Theory and Practice, Vol. 33 No. 5, pp. 1001-1022.

European Crowdfunding Network (2017), "Review of crowdfunding regulation", 2017. Interpretations of Existing Regulation Concerning Crowdfunding in Europe, North America, and Israel, available at: www.eurocrowd.org.

Fogel, K. (2006), "Oligarchic family control, social economic outcomes, and the quality of government", Journal of International Business Studies, Vol. 37 No. 5, pp. 603-622.

Hoang, H. and Antoncic, B. (2003), "Network-based research in entrepreneurship: a critical review", Journal of Business Venturing, Vol. 18 No. 2, pp. 165-187.

Hwang, H. and Powell, W.W. (2005), "Institutions and entrepreneurship", Handbook of Entrepreneurship Research, Springer, Boston, MA, pp. 201-232.

Ibrahim, D.M. (2015), "Equity crowdfunding: a market for lemons", Minnesota Law Review, Vol. 100, p. 561.

Ingram, P. and Silverman, B. (2002), The New Institutionalism in Strategic Management, Elsevier, New York, NY. 
Klepper, S. and Simons, K.L. (2000), "Dominance by birthright: entry of prior radio producers and competitive ramifications in the US television receiver industry", Strategic Management Journal, Vol. 21 Nos 10-11, pp. 997-1016.

Mollick, E.R. and Kuppuswamy, V. (2014), After the Campaign: Outcomes of Crowdfunding, UNC Kenan-Flagler Research Paper, (2376997).

Najjarian, I.D.N. (2013), "O crowdfunding ea oferta publica de valores", FMU Direito-Revista Eletrônica, Vol. 26, p. 37.

Nanda, R. and Sørensen, J.B. (2010), "Workplace peers and entrepreneurship”, Management Science,

Regulating the equity-based crowdfunding

Robb, A.M. and Robinson, D.T. (2014), "The capital structure decisions of new firms", Review of Financial Studies, Vol. 27 No. 1, pp. 153-179.

Schumpeter, J. (1934), "the theory of economic development, translated by Redvers Opie", Harvard: Economic Studies, Vol. 46, pp. 1600-0404.

Surowiecki, J. (2004), "The wisdom of crowds: why the many are smarter than the few and how collective wisdom shapes business", Economies, Societies and Nations, Doubleday \& Co.

Welter, F. (2011), "Contextualizing entrepreneurship - conceptual challenges and ways forward", Entrepreneurship: Theory and Practice, Vol. 35 No. 1, pp. 165-184.

Williamson, O.E. (2000), “The new institutional economics: taking stock, looking ahead”, Journal of Economic Literature, Vol. 38 No. 3, pp. 595-613.

Zhang, J. and Liu, P. (2012), "Rational herding in microloan markets", Management Science, Vol. 58 No. 5, pp. 892-912.

\section{Appendix}

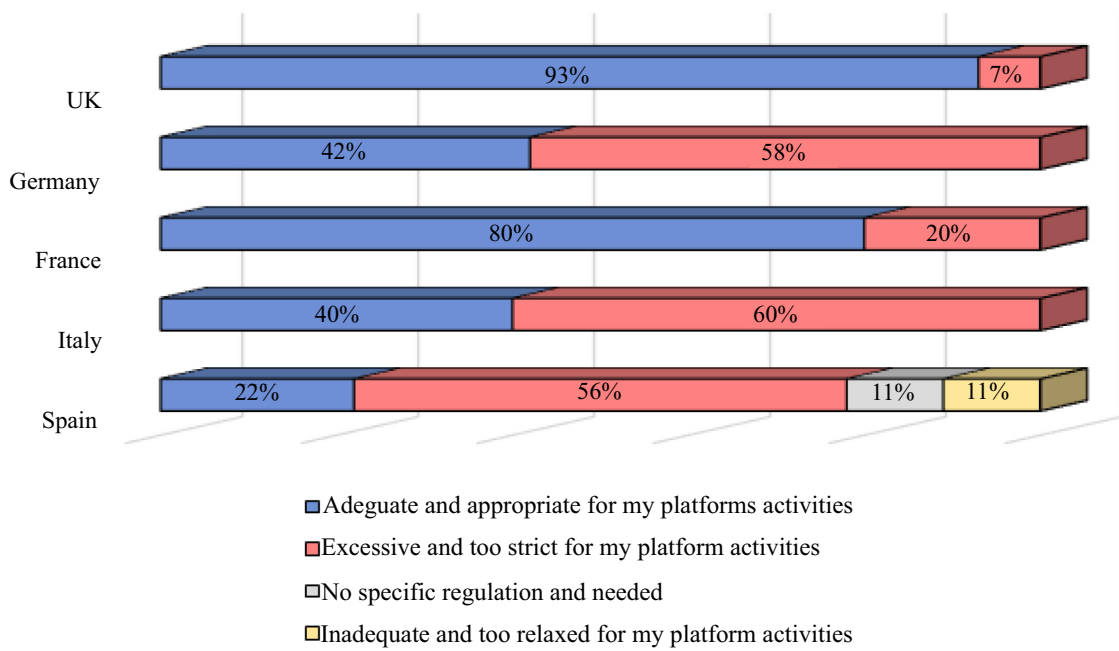

Source(s): Authors' elaboration with data from Ziegler et al. (2018), and Zhang et al. (2017)

Figure A1. Platforms' perception of existing national regulation by country 


\section{JEPP \\ 10,2}

260

Figure A2.

Percentages of

European investors responding to the question: How are the platforms you use regulated?

Figure A3.

Percentages of European investors responding to the question: Does regulation increase your trust in equity crowdfunding?

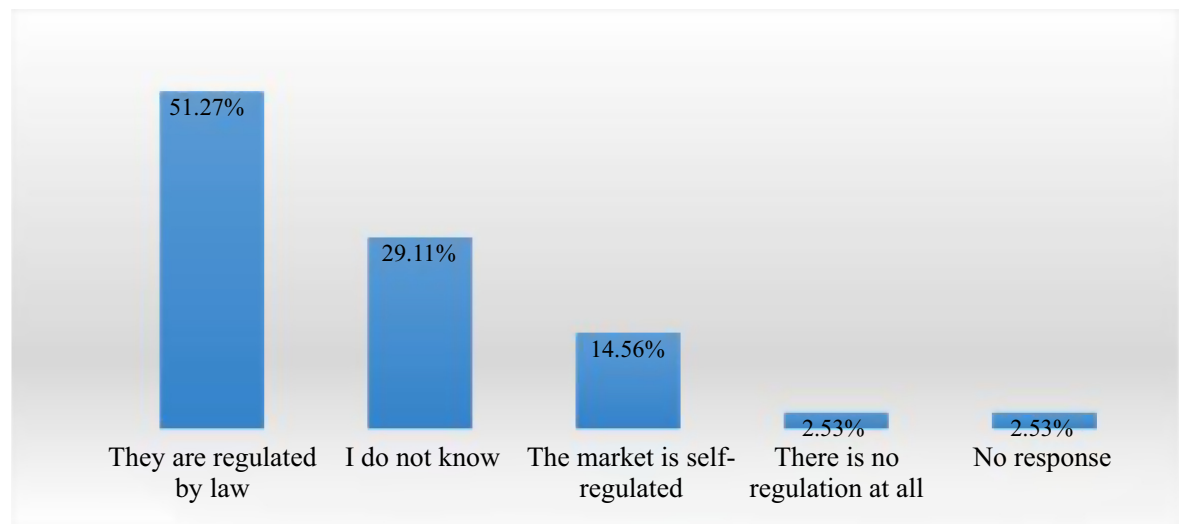

Source(s): Authors' elaboration with data from the European Commission report (2017)

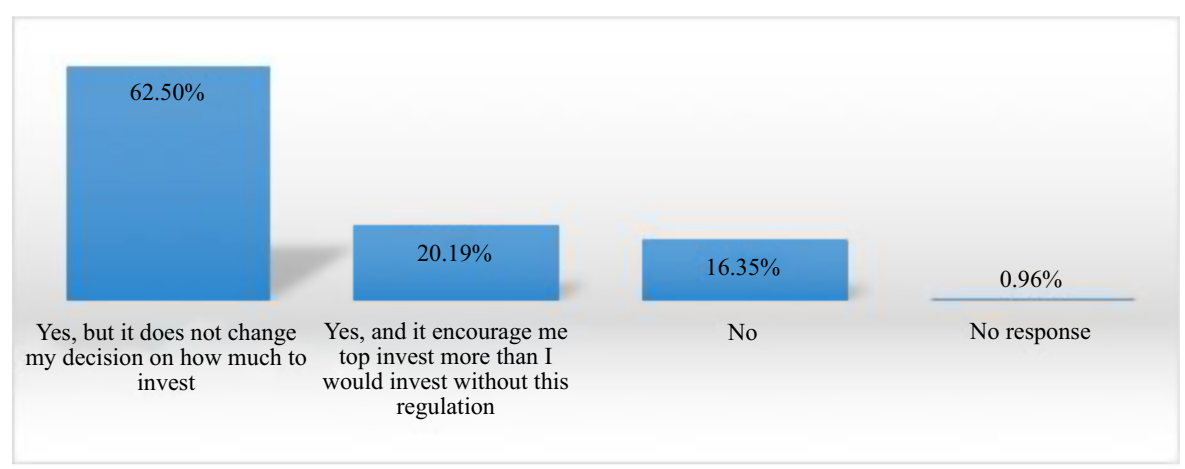

Source(s): Authors' elaboration with data from the European Commission report (2017)

\section{Corresponding author}

Antonella Francesca Cicchiello can be contacted at: antonellacicchiello@hotmail.it

For instructions on how to order reprints of this article, please visit our website:

www.emeraldgrouppublishing.com/licensing/reprints.htm

Or contact us for further details: permissions@emeraldinsight.com 